\title{
IMPLEMENTASI METODE PROFILE MATCHING PADA PENJURUSAN BIDANG MINAT SISWA (Studi kasus di SMA 12 Semarang)
}

\author{
Wulandari Yuniar $\mathrm{P}^{1}$, Muljono ${ }^{2}$ \\ ${ }^{12}$ Teknik Informatika, Universitas Dian Nuswantoro \\ E-mail: 111201508980@mhs.dinus.ac.id,muljono@dsn.dinus.ac.id
}

\begin{abstract}
Class X high school students have not been able to determine what area of interest they should choose due to lack of knowledge. Although the principal and teachers have provided direction to students, they have not fully provided solutions to problems faced by class X SMA students. In addition, schools are also required to continue to compete with each other to have good quality students and advance the quality of schools, so that systems or technologies that support majors must also be established to support school accreditation. The ability to reasoning based on data similarity or profile matching is one of the main elements in a knowledge-based system. The ability in knowledge-based systems is able to define similarity very well. The results of experiments carried out by calculating profile matching can provide comparisons, in the science class specialization of 192 students, only $84 \%$ of those who are positive can enter. Meanwhile, if the social studies class is interested in all 192 students, all of them can enter. So that the system implemented with the Profile Matching method will be able to help as well as be additional support for $X$ grade high school students who want to register for school specialization.
\end{abstract}

Keywords: Profile Matching Method, Majoring Class X SMA

\begin{abstract}
Abstrak
Siswa kelas X SMA belum dapat menentukan bidang minat apa yang harus mereka pilih disebabkan oleh pengetahuan yang kurang. Meskipun kepala sekolah serta guru telah memberikan pengarahan pada siswa, namun tidak sepenuhnya memberikan solusi masalah yang dihadapi siswa kelas X SMA. Selain itu sekolah juga dituntut untuk terus saling bersaing untuk memiliki kualitas siswa yang baik dan memajukan kualitas sekolah, sehingga sistem atau teknologi yang mendukung penjurusan juga harus diadakan untuk mendukung akreditas sekolahan. Kemampuan penalaran berbasis kemiripan data atau profile matching adalah salah satu elemen utama pada sistem berbasis pengetahuan. Kemampuan pada sistem berbasis pengetahuan mampu mendefinisikan kemiripan dengan sangat baik. Hasil percobaan yang dilakukan perhitungan profile matching dapat memberikan perbandingan, pada peminatan kelas IPA siswa sebanyak 192 hanya $84 \%$ saja yang positif bisa masuk. Sedangkan jika peminatan kelas IPS seluruh siswa sebanyak 192 semuanya bisa masuk. Sehingga dengan adanya sistem yang diterapkan dengan metode Profile Matching ini akan dapat membantu sekaligus menjadi tambahan dukungan dalam siswa SMA kelas X yang ingin mendaftar peminatan sekolah.
\end{abstract}

Kata Kunci : Metode Profile Matching, Penjurusan siswa kelas X SMA 


\section{PENDAHULUAN}

Mengenai pemilihan bidang Siswa kelas X SMA Negeri 12 Semarang, siswa masih belum dapat menentukan bidang minat apa yang harus mereka pilih disebabkan oleh pengetahuan yang kurang. Meskipun kepala sekolah serta guru telah memberikan pengarahan pada siswa, namun tidak sepenuhnya memberikan solusi masalah yang dihadapi siswa kelas X SMA Negeri 12 Semarang. Dalam hal ini, peneliti memberi gagasan dengan membangun sistem yang dapat memprediksi bidang minat untuk membantu menambah keyakinan para siswa kelas X sekolah SMA Negeri 12 Semarang (Wisnu, 2019). Selain itu sekolah juga dituntut untuk terus saling bersaing untuk memiliki kualitas siswa yang baik dan memajukan kualitas sekolah, sehingga sistem atau teknologi yang mendukung penjurusan juga harus diadakan untuk mendukung akreditas sekolahan.

Pihak sekolah mempunyai hak dalam menentukan potensi yang dimiliki oleh siswasiswinya. Untuk memfokuskan kualitas siswasiswinya pihak sekolah perlu mengelompokkan minat kemampuan siswa berdasarkan nilai mata pelajaran. Sehubungan dengan hal tersebut pihak sekolah berharap dengan adanya pengelompokan minat kemampuan siswa berdasarkan nilai mata pelajaran dapat mempermudah pihak sekolah dalam meningkatkan kualitas siswa-siswinya dalam memilih sekolah setelah lulus. Selain itu, pengelompokan minat kemampuan siswa tersebut lebih efektif karena para guru tidak berfokus membimbing hanya pada siswa yang dirasa mampu untuk mengembangkan kemampuannya. Seperti yang sebelumnya para guru hanya berfokus membimbing pada siswa yang mampu mengembangkan kemampuannya sehingga hal tersebut tidak efisien dengan situasi yang semestinya.

Dari penumpukan nilai siswa yang disimpan sekolahan, seharusnya bisa dimanfaatkan untuk pembuatan sistem berbasis informasi. Seperti sistem seleksi, Pohon Keputusan, Jaringan Syaraf Tiruan, Naïve Bayes, K-Nearest Neighbor dan banyak lainnya. Teknik-teknik itu dapat dimanfaatkan untuk menemukan sebuah informasi baru yang dapat digunakan, seperti klasifikasi peminatan jurusan atau prediksi tentang peminatan jurusan dan sebagainya (Maghari \& Alfere, 2018). Kemampuan penalaran berbasis kemiripan data atau profile matching adalah salah satu elemen utama pada sistem berbasis pengetahuan. Kemampuan pada sistem berbasis pengetahuan mampu mendefinisikan kemiripan dengan sangat baik (Tyas, 2015).

Dalam hal ini Profile matching juga bisa dimanfaatkan untuk memprediksi minat siswa karena profile matching pengetahuan mampu mendefinisikan kemiripan dengan sangat baik. Dengan cara mencocokan nilai-nilai aspek yang digunakan apakah cocok dengan dataset yang ditentukan dan akan menghitung jarak nilai dari batas minimal dengan nilai tersebut (Farid \& Firliana, 2017). Dalam profile matching terdapat langkah penentuan GAP, yaitu selisih perbedaan antara kompetensi siswa dengan kompetensi jurusan yang akan ditempatinya nanti. Sangat cocok jika diterapkan pada bidang minat seperti sekolahan

\section{METODE PENELITIAN}

2.1 Pemilihan Bidang Minat

Pada SMA biasanya terdapat dua peminatan untuk penjurusan siswa yaitu IPA dan IPS. Seolah-olah tingkat kecerdasan siswa itu cuma dibagi jadi dua tolak ukur saja yaitu hitungan untuk IPA dan hafalan untuk IPS. Jika siswa jago hitungan ya itu tandanya cocok masuk ke jurusan IPA, sebaliknya jika suka hafalan berarti cocok masuk jurusan IPS (Wibowo, 2019). Pernyataan tersebut tidak benar, tidak ada satupun pelajaran hitungan di IPA, baik Fisika, Kimia, dan Biologi itu sama sekali bukan pelajaran berhitung. Kalaupun ada yang namanya pelajaran berhitung, yang paling dekat itu ya pelajaran Akuntansi, itu pun malah dia lebih pas masuk ke jurusan IPS. Begitu juga sebaliknya, tidak ada satupun pelajaran di IPS yang menuntut hafalan, kalo sekarang di jurusan IPS masih banyak menghafal materi pelajaran, berarti cara belajar yang keliru.

Baik Sejarah, Sosiologi, Ekonomi, maupun Geografi itu pelajaran yang menuntut pemahaman konseptual yang komprehensif. Ketika konsepnya sudah 
mengerti, maka dengan sendirinya kita akan hafal sama istilah-istilah yang digunakan. Berdasarkan Bloom's Taxonomy, kemampuan manusia dalam domain kognitif terbagi menjadi tiga aspek, yaitu (Wibowo, 2019):

1. Level 1: Knowledge, yang termasuk dalam knowledge adalah pengetahuan kita mengenai fakta-fakta atau terminologi yang spesifik, pengetahuan mengenai metode-metode tertentu, dan pengetahuan mengenai prinsip-prinsip dan teori-teori universal.

2. Level 2: Comprehension, Sedangkan comprehension merupakan kemampuan kognitif yang melibatkan kemampuan untuk memahami konsep, membandingkan konsep, menginterpretasikan suatu fenomena atau abstraksi tertentu, dan dapat menyimpulkan main idea dari pembahasan-pembahasan tertentu.

3. Level 3: Critical Thinking, terdiri dari beberapa dimensi, yaitu: analysis, evaluation, synthesis.

a. Analysis: menguji dan menguraikan informasi dan/atau pengetahuan dengan cara mengidentifikasi komponen-komponen dari informasi tersebut (misalnya: penyebab, efek, dan prevalensi)

b. Evaluation: mengajukan dan mempertahankan opini dengan cara membuat penilaian mengenai informasi dari gagasan berdasarkan dengan kriteria-kriteria tertentu.

c. Synthesis: mengumpulkan informasi-informasi terkait suatu gagasan tertentu untuk membuat suatu kesimpulan dan menghasilkan gagasan alternatif.

2.2 Tahapan Preprocessing

Pada pemrosesan data terdapat preprocessing yaitu dilakukan dinormalisasi dimana data yang yang akan digunakan akan dilakukan proses tahap awal dulu. Pada deretan data terdapat 2 penilaian yaitu teori dan praktek, sehingga proses awal yang harus dilakukan adalah mencari nilai rata-rata dari kedua penilaian, sehingga didapatkan nilai tunggal yang akan digunakan untuk proses input. Gambaran alur preprocessing seperti gambar berikut ini :

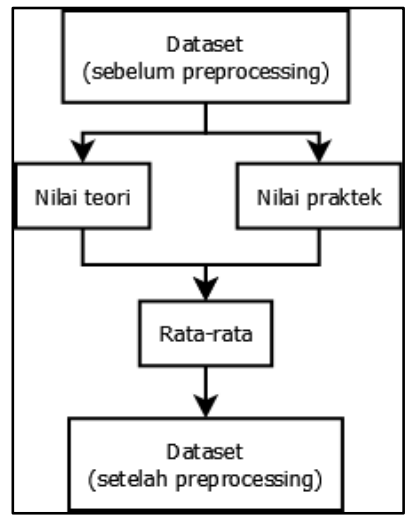

Gambar 1 Alur preprocessing

Keterangan :

1. Dataset sebelum preprocessing adalah dataset asli yang didapatkan dari SMA 12 Semarang

2. Dataset adalah data nilai yang meliputi nilai teori dan nilai praktek

3. Didapatkan nilai rata-rata dari nilai teori dan nilai praktek

4. Nilai rata-rata adalah dataset yang telah di preprocessing

\subsection{Skenario Penentuan Kriteria Factor}

Dalam profile matching terdapat kriteria yang disebut sebagai core factor dan secondary factor. Pada penelitian ini core factor dan secondary factor ditentukan oleh pihak sekolahan, berikut ini ada rencana pemberian bobot pada core factor dan secondary factor pada masingmasing kriteria. Contoh pengambilan tipe untuk bidang minat diambil berdasarkan decision making dilihat dari kebutuhan sekolah antara IPA dan IPS. 
Tabel 1 Kriteria Factor (Wisnu, 2019)

\begin{tabular}{|l|l|}
\hline \multicolumn{2}{|l|}{ Kriteria tipe untuk penjurusan IPA } \\
\hline ATRIBUT & Tipe \\
\hline Nilai Matematika & Core Factor \\
\hline Nilai B. Indonesia & Core Factor \\
\hline Nilai B. Inggris & Secondary Factor \\
\hline Nilai Fisika & Core Factor \\
\hline Nilai Kimia & Core Factor \\
\hline Nilai Sejarah & Secondary Factor \\
\hline Nilai Geografi & Secondary Factor \\
\hline Nilai Ekonomi & Secondary Factor \\
\hline Nilai Sosiologi & Secondary Factor \\
\hline Nilai Biologi & Core Factor \\
\hline
\end{tabular}

Keterangan :

Kriteria diambil dari kesepakatan Tata Kesiswaan yang memberikan studi kasus untuk penelitian, pada penjurusan kelas IPA seperti pada tabel 1 diatas.

Tabel 2 Kriteria Factor (Wisnu, 2019)

\begin{tabular}{|l|l|}
\hline \multicolumn{2}{|l|}{ Kriteria tipe untuk penjurusan IPS } \\
\hline ATRIBUT & Tipe \\
\hline Nilai Matematika & Secondary Factor \\
\hline Nilai B. Indonesia & Core Factor \\
\hline Nilai B. Inggris & Secondary Factor \\
\hline Nilai Fisika & Secondary Factor \\
\hline Nilai Kimia & Secondary Factor \\
\hline Nilai Sejarah & Core Factor \\
\hline Nilai Geografi & Core Factor \\
\hline Nilai Ekonomi & Core Factor \\
\hline Nilai Sosiologi & Core Factor \\
\hline Nilai Biologi & Secondary Factor \\
\hline
\end{tabular}

Keterangan :

Kriteria diambil dari kesepakatan Tata Kesiswaan yang memberikan studi kasus untuk penelitian, pada penjurusan kelas IPS seperti pada tabel 2 diatas. 
Setelah mendapatkan nilai yang valid dari preprocessing dan menetukan factor kriteria, selanjutnya pemrosesan profile matching dari peminatan siswa, penggambaran proses dengan profile matching sebagai berikut :

Tabel 3 Tabel Contoh 1

\begin{tabular}{|l|c|c|c|}
\hline Mata Pelajaran & $\begin{array}{l}\text { Set Profile } \\
\text { matching IPA } \\
\text { Contoh }\end{array}$ & $\begin{array}{l}\text { Set Profile } \\
\text { matching IPS } \\
\text { Contoh }\end{array}$ & $\begin{array}{l}\text { Nilai Pelajaran } \\
\text { Siswa Contoh }\end{array}$ \\
\hline Nilai Matematika & 6 & 8 & 6 \\
\hline Nilai B. Indonesia & 5 & 8 & 7 \\
\hline Nilai B. Inggris & 7 & 8 & 6 \\
\hline Nilai Fisika & 8 & 5 & 7 \\
\hline Nilai Kimia & 9 & 7 & 8 \\
\hline Nilai Sejarah & 7 & 6 & 4 \\
\hline Nilai Geografi & 7 & 4 & 6 \\
\hline Nilai Ekonomi & 8 & 7 & 7 \\
\hline Nilai Sosiologi & 5 & 8 & 8 \\
\hline Nilai Biologi & 7 & 9 & 7 \\
\hline
\end{tabular}

Tabel 4 Tabel Hasil Contoh 2

\begin{tabular}{|l|c|c|}
\hline & Jurusan IPA & Jurusan IPS \\
\hline $\begin{array}{l}\text { Hasil Penilaian Profile } \\
\text { Matching }\end{array}$ & $\ldots \%$ & $\ldots \%$ \\
\hline
\end{tabular}

Berdasarkan persentase tersebut maka siswa dengan NIS dan Nomor $\mathrm{N}$ direkomendasikan masuk jurusan (IPA/IPS) dengan persentase $\mathrm{N}$ persen.

\subsection{Metode Profile Matching}

Profile matching adalah mekanisme pengambilan keputusan yang mengasumsikan bahwa terdapat tingkatan variabel prediktor ideal yang harus terpenuhi oleh subyek/data yang diteliti, bukan berarti tingkat minimal yang harus terpenuhi atau terlewati (id, 2018). Proses perhitungan metode Profile Matching diawali dengan pendefinisian nilai-nilai minimum untuk setiap variabel yang kemudian dijadikan gap dan diberi bobot. Setiap variabel akan dihitung berdasarkan rata-rata variabel Core Factor (CF) dan Secondary Factor (SF) (Gautama, 2017). Sebelum menghitung CF dan SF ada langkah-langkah yang harus dilakukan untuk menghitung gap pada profile matching. Langkah-langkah metode Profile Matching :
1. Menentukan data-data yang dibutuhkan antara lain data nilai UN Matematika, Fisika, Kimia, Biologi, Bahasa Indonesia, Bahasa Inggris dan hasil jawaban kuesioner yang telah disediakan .

2. Menentukan aspek yang digunakan dalam penilaian.

3. Pemetaan Gap Profile.

\section{Gap $=$ Profil Minimal - Profile Data}

4. Memberikan bobot nilai setiap Gap.

5. Menghitung Core Factor dan Secondary Factor

Core Factor adalah kriteria data yang paling dibutuhkan dalam suatu penilaian karena dengan adanya Core Factor ini dapat diperoleh hasil yang optimal.

Core Factor dirumuskan dengan : NFC $=$ ENC $/$ EIC 
Keterangan:

NFC : Nilai rata-rata core factor

NC : Jumlah total nilai core factor

IC : Jumlah item core factor

Secondary Factor adalah kriteria data yang tidak termasuk Core Factor atau bisa dibilang faktor pendukung yang dibutuhkan dalam suatu penilaian.

Soft Factor dirumuskan dengan :

$$
\text { NFS = ENS / EIS }
$$

Keterangan:

NFS : Nilai rata-rata secondary factor

NS : Jumlah total nilai secondary factor

IS : Jumlah item secondary factor

6. Menghitung nilai total. Nilai total diperoleh dari prosentase Core

Factor (CF) dan Secondary Factor (SF).

Nilai total dirumuskan :

$$
\mathrm{N}=(\mathrm{x}) \% \mathrm{NCF}+(\mathrm{x}) \% \mathrm{NSF}
$$

Keterangan:

$\mathrm{N}$ : Nilai Total dari kriteria

NFS : Nilai rata-rata

secondary factor

NFC : Nilai rata-rata core

factor
(x) $\% \quad$ : Nilai persen yang
diinputkan

7. Menghitung penentuan ranking.

Penentuan ranking sendiri

merupakan hasil akhir dari Metode

Profile Matching.

Ranking $=(\mathrm{x}) \% \mathrm{NMA}+(\mathrm{x}) \% \mathrm{NSA}$

Keterangan :

NMA : Nilai total kriteria

Aspek Utama

NSA : Nilai total kriteria

Aspek Pendukung

(x) $\% \quad$ : Nilai persen yang
diinputkan
2.5 Kelebihan Metode Profile Matching

Berikut ini merupakan uraian tentang kelebihan dan juga kekurangan tentang Profile Matching.

Kelebihan Profile Matching yaitu,

1. Untuk membandingkan antara kompetensi individu masing-masing, metode ini sangat cocok digunakan, untuk mengetahui suatu profile individu sehingga diketahui perbedaanya.

2. Sangat cocok digunakan sebagai pengambil keputusan yang berhubungan dengan nilai keputusan yang memiliki nilai prestasi dan kompetensi, karena perhitungannya menggunakan pembobotan dan perhitungan gap.

3. Profile matching juga memiliki penilaian logis dan konsisten dibanding dengan metode yang lain, sehingga alternatif yang diberikan juga lebih baik (Cahya, 2018).

Sedangkan kekurangan Profile Matching yaitu,

1. Tidak memperhitungkan daya tahan atau ketahanan hasil output yang sudah dianalisis pengambilan keputusan.

2. Profile matching tidak digunakan oleh multi objek dan multi kriteria yang berdasarkan pada perbandingan tiap elemen yang digunakan (Cahya, 2018).

\section{HASIL DAN PEMBAHASAN}

3.1 Hasil Penerapan Profile Matching

Dalam percobaan perhitungan manual ini akan mencoba menghitung dengan dataset sebanyak 192 record data uji. Kemudian data diambil secara random 20\% atau sebanyak 38 record sebagai data training. Berikut ini adalah langkah-langkah hitungan manual yang dipakai untuk data menggunakan metode profile matching. Penjelasan ini dibutuhkan untuk mengetahui alur dari hitungan metode sehingga mendapatkan output atau hasil. Berikut ini adalah rumus bertahap metode. Konversi nilai 
menjadi empat bagian yaitu angka $1,2,3$, dan 4. Dengan ketentuan nilai 4 adalah pembagian nilai tertinggi. Berikut ini pembagian range nilainya.
Tabel 5 Tabel Range Konversi

\begin{tabular}{|c|c|}
\hline Nilai asli & Konversi Nilai \\
\hline$\geq 85$ & 4 \\
\hline $80-84$ & 3 \\
\hline $76-79$ & 2 \\
\hline$\leq 75$ & 1 \\
\hline
\end{tabular}

Berikut ini adalah dataset yang sudah dikonversi :

\begin{tabular}{|r|c|c|c|c|c|c|c|c|c|c|}
\hline ID & MAT & BIN & ING & FIS & KIM & SEJ & GEO & EKO & SOS & BIO \\
\hline 1 & 3 & 4 & 2 & 4 & 2 & 3 & 4 & 3 & 3 & 3 \\
\hline 2 & 4 & 3 & 4 & 4 & 3 & 4 & 4 & 4 & 4 & 3 \\
\hline 3 & 3 & 3 & 3 & 4 & 3 & 3 & 4 & 3 & 4 & 3 \\
\hline 4 & 3 & 3 & 3 & 4 & 2 & 3 & 3 & 3 & 4 & 3 \\
\hline 5 & 3 & 3 & 3 & 4 & 3 & 3 & 3 & 3 & 3 & 3 \\
\hline$\ldots$ & $\ldots$ & $\ldots$ & $\ldots$ & $\ldots$ & $\ldots$ & $\ldots$ & $\ldots$ & $\ldots$ & $\ldots$ & $\ldots$ \\
\hline 38 & 3 & 3 & 3 & 4 & 3 & 3 & 3 & 3 & 4 & 3 \\
\hline
\end{tabular}

1. Berikut ini adalah perhitungan GAP dari dataset untuk profile matching kelas IPA. Dicontohkan pada data ID 1 dan seterusnya adalah sudah hasil.

Tabel 6 Nilai Profile Minimal IPA

\begin{tabular}{|c|c|c|c|c|c|c|c|c|c|}
\hline \multicolumn{10}{|c|}{ Nilai Profile Minimal } \\
\hline MAT & BIN & ING & FIS & KIM & SEJ & GEO & EKO & SOS & BIO \\
\hline 4 & 3 & 2 & 3 & 3 & 1 & 1 & 1 & 1 & 4 \\
\hline
\end{tabular}

Tabel 7 Pemetaan Nilai GAP, Nilai Siswa Dikurangi Nilai Minimal IPA

\begin{tabular}{|c|c|c|c|c|c|c|c|c|c|c|}
\hline ID & MAT & BIN & ING & FIS & KIM & SEJ & GEO & EKO & SOS & BIO \\
\hline & $\begin{array}{c}3-4=- \\
1\end{array}$ & $\begin{array}{c}4- \\
3=1\end{array}$ & $\begin{array}{c}2- \\
2=0\end{array}$ & $\begin{array}{c}4- \\
3=1\end{array}$ & $2-3=-1$ & $\begin{array}{c}3- \\
1=2\end{array}$ & $\begin{array}{c}4- \\
1=3\end{array}$ & $\begin{array}{c}3- \\
1=2\end{array}$ & $\begin{array}{c}3- \\
1=2\end{array}$ & $3-4=-1$ \\
\hline 2 & 0 & 0 & 2 & 1 & 0 & 3 & 3 & 3 & 3 & -1 \\
\hline 3 & -1 & 0 & 1 & 1 & 0 & 2 & 3 & 2 & 3 & -1 \\
\hline 4 & -1 & 0 & 1 & 1 & -1 & 2 & 2 & 2 & 3 & -1 \\
\hline 5 & -1 & 0 & 1 & 1 & 0 & 2 & 2 & 2 & 2 & -1 \\
\hline$\ldots$ & $\ldots$ & $\ldots$ & $\ldots$ & $\ldots$ & $\ldots$ & $\ldots$ & $\ldots$ & $\ldots$ & $\ldots$ & $\ldots$ \\
\hline 38 & -1 & 0 & 1 & 1 & 0 & 2 & 2 & 2 & 3 & -1 \\
\hline
\end{tabular}

2. Berikut ini adalah perhitungan GAP dari dataset untuk profile matching kelas IPA. Dicontohkan pada data ID 1 dan seterusnya adalah sudah hasil. 
Implementasi Metode Profile Matching Pada Penjurusan Bidang Minat Siswa (Studi kasus di SMA 12 Semarang)

Tabel 8 Nilai Profile Minimal IPS

\begin{tabular}{|c|c|c|c|c|c|c|c|c|c|}
\hline \multicolumn{10}{|c|}{ Nilai Profile Minimal } \\
\hline MAT & BIN & ING & FIS & KIM & SEJ & GEO & EKO & SOS & BIO \\
\hline 3 & 3 & 3 & 1 & 1 & 4 & 4 & 3 & 3 & 2 \\
\hline
\end{tabular}

Tabel 9 Pemetaan Nilai GAP, Nilai Siswa Dikurangi Nilai Minimal IPS

\begin{tabular}{|c|c|c|c|c|c|c|c|c|c|c|}
\hline ID & MAT & BIN & ING & FIS & KIM & SEJ & GEO & EKO & SOS & BIO \\
\hline & $3-3=0$ & $\begin{array}{c}4- \\
3=1\end{array}$ & $2-3=-1$ & $\begin{array}{c}4- \\
1=3\end{array}$ & $\begin{array}{c}2- \\
1=1\end{array}$ & $3-4=-1$ & $\begin{array}{c}4- \\
4=0\end{array}$ & $\begin{array}{c}3- \\
3=0\end{array}$ & $\begin{array}{c}3- \\
3=0\end{array}$ & $3-2=1$ \\
\hline 2 & 1 & 0 & 1 & 3 & 2 & 0 & 0 & 1 & 1 & 1 \\
\hline 3 & 0 & 0 & 0 & 3 & 2 & -1 & 0 & 0 & 1 & 1 \\
\hline 4 & 0 & 0 & 0 & 3 & 1 & -1 & -1 & 0 & 1 & 1 \\
\hline 5 & 0 & 0 & 0 & 3 & 2 & -1 & -1 & 0 & 0 & 1 \\
\hline$\ldots$ & $\ldots$ & $\ldots$ & $\ldots$ & $\ldots$ & $\ldots$ & $\ldots$ & $\ldots$ & $\ldots$ & $\ldots$ & $\ldots$ \\
\hline 38 & 0 & 0 & 0 & 3 & 2 & -1 & -1 & 0 & 1 & 1 \\
\hline
\end{tabular}

3. Menghitung Pemberian Pembobotan Dari Hasil GAP

Setelah diperoleh GAP pada masing-masing individu, kemudian diberikan bobot masingmasing sesuai ketentuan tabel penilaian yang telah dibuat sebelumnya (Cahya, 2018) yaitu,

Tabel 10 Tabel Pembobotan

\begin{tabular}{|c|c|c|l|}
\hline No & Selisih gab & Bobot nilai & \multicolumn{1}{|c|}{ Keterangan } \\
\hline 1 & 0 & 5 & Kemampuan seperti yang di butuhkan \\
\hline 2 & 1 & 4.5 & Kemampuan individu melebihi 1 tingkat \\
\hline 3 & -1 & 4 & Kemampuan individu kurang dari 1 tingkat \\
\hline 4 & 2 & 3.5 & Kemampuan individu melebihi 2 tingkat \\
\hline 5 & -2 & 3 & Kemampuan individu kurang dari 2 tingkat \\
\hline 6 & 3 & 2.5 & Kemampuan individu melebihi 3 tingkat \\
\hline 7 & -3 & 2 & Kemampuan individu kurang dari 3 tingkat \\
\hline 8 & 4 & 1.5 & Kemampuan individu melebihi 4 tingkat \\
\hline 9 & -4 & 1 & Kemampuan individu kurang dari 4 tingkat \\
\hline
\end{tabular}

Dari hasil ID 1 diperoleh nilai GAP matematika yaitu (-1) artinya pada pembobotan hasil GAP, nilai akan dikonversi menjadi bobot nilai 4, seperti ketentuan pada tabel 4.9 diatas.

Tabel 9 Pembobotan Hasil Nilai GAP IPA

\begin{tabular}{|c|c|c|c|c|c|c|c|c|c|c|}
\hline ID & MAT & BIN & ING & FIS & KIM & SEJ & GEO & EKO & SOS & BIO \\
\hline 1 & 4 & 4,5 & 5 & 4,5 & 4 & 3,5 & 2,5 & 3,5 & 3,5 & 4 \\
\hline 2 & 5 & 5 & 3,5 & 4,5 & 5 & 2,5 & 2,5 & 2,5 & 2,5 & 4 \\
\hline 3 & 4 & 5 & 4,5 & 4,5 & 5 & 3,5 & 2,5 & 3,5 & 2,5 & 4 \\
\hline 4 & 4 & 5 & 4,5 & 4,5 & 4 & 3,5 & 3,5 & 3,5 & 2,5 & 4 \\
\hline 5 & 4 & 5 & 4,5 & 4,5 & 5 & 3,5 & 3,5 & 3,5 & 3,5 & 4 \\
\hline$\ldots$ & $\ldots$ & $\ldots$ & $\ldots$ & $\ldots$ & $\ldots$ & $\ldots$ & $\ldots$ & $\ldots$ & $\ldots$ & $\ldots$ \\
\hline 38 & 4 & 5 & 4,5 & 4,5 & 5 & 3,5 & 3,5 & 3,5 & 2,5 & 4 \\
\hline
\end{tabular}


Tabel 12 Pembobotan Hasil Nilai GAP IPS

\begin{tabular}{|c|c|c|c|c|c|c|c|c|c|c|}
\hline ID & MAT & BIN & ING & FIS & KIM & SEJ & GEO & EKO & SOS & BIO \\
\hline 1 & 5 & 4,5 & 4 & 2,5 & 4,5 & 4 & 5 & 5 & 5 & 4,5 \\
\hline 2 & 4,5 & 5 & 4,5 & 2,5 & 3,5 & 5 & 5 & 4,5 & 4,5 & 4,5 \\
\hline 3 & 5 & 5 & 5 & 2,5 & 3,5 & 4 & 5 & 5 & 4,5 & 4,5 \\
\hline 4 & 5 & 5 & 5 & 2,5 & 4,5 & 4 & 4 & 5 & 4,5 & 4,5 \\
\hline 5 & 5 & 5 & 5 & 2,5 & 3,5 & 4 & 4 & 5 & 5 & 4,5 \\
\hline$\ldots$ & $\ldots$ & $\ldots$ & $\ldots$ & $\ldots$ & $\ldots$ & $\ldots$ & $\ldots$ & $\ldots$ & $\ldots$ & $\ldots$ \\
\hline 38 & 5 & 5 & 5 & 2,5 & 3,5 & 4 & 4 & 5 & 4,5 & 4,5 \\
\hline
\end{tabular}

4. Menghitung Core Factor dan Secondary Factor dari Hasil Pembobotan GAP

Untuk penentuan core factor dan secondary factor ini dilakukan oleh administrator, dalam penelitian ini ditentukan oleh Tata Usaha pihak sekolah (Wisnu, 2019). Setelah penentuan bobot GAP selesai, kemudian nilai akhir bobot dikelompokkan menjadi 2 bagian yaitu bagian Core Factor dan secondary factor.

Contoh perhitungan untuk kelas IPA :

Core Factor $\mathrm{N}_{\mathrm{CF}}(\mathrm{A})=$

$($ Matematika $)+($ B. Indonesia $)+($ Fisika $)+($ Kimia $)+($ Biologi $) / 5$

Secondary Factor $\mathrm{N}_{\mathrm{SF}}(\mathrm{A})=$

Nilai Total IPA

(B.Inggris $)+($ Sejarah $)+($ Geografi $)+($ Ekonomi $)+($ Sosiologi $) / 5$

Contoh perhitungan untuk kelas IPS :

Core Factor $\mathrm{N}_{\mathrm{CF}}(\mathrm{S})=$

$($ B. Indonesia $)+($ Sejarah $)+($ Geografi $)+($ Ekonomi $)+($ Sosiologi $) / 5$

Secondary Factor $\mathrm{N}_{\mathrm{SF}}(\mathrm{S})=$

Nilai Total IPS $\quad=\left(\mathrm{N}_{\mathrm{CF}}(\mathrm{s})\right)+\left(\mathrm{N}_{\mathrm{SF}}(\mathrm{s})\right)$

(Matematika) $n+($ B.Inggris $)+($ Fisika $)+($ Kimia $)+($ Biologi $) / 5$

Tabel 103 Hasil Akhir Nilai Kelas IPA

\begin{tabular}{|c|l|c|c|}
\hline ID & $\begin{array}{l}\text { Core Factor } \mathrm{N}_{\mathrm{CF}}(\mathrm{A})= \\
(\text { Matematika }+(\mathrm{B} \text {. Indonesia) }+ \\
(\text { Fisika })+(\text { Kimia })+(B i o l o g i) \\
5\end{array}$ & $\begin{array}{l}\text { Secondary Factor } \mathrm{N}_{\mathrm{SF}}(\mathrm{A})= \\
(\text { B.Inggris })+(\text { Sejarah) } \\
(\text { Geografi })+(\text { Ekonomi) } \\
\text { (Sosiologi) } / 5\end{array}$ & $\begin{array}{c}\text { Nilai } \\
\text { Total }\end{array}$ \\
\hline 1 & 4,2 & 3,6 & 7,8 \\
\hline 2 & 4,7 & 2,7 & 7,4 \\
\hline 3 & 4,5 & 3,3 & 7,8 \\
\hline 4 & 4,3 & 3,5 & 7,8 \\
\hline 5 & 4,5 & 3,7 & 8,2 \\
\hline$\ldots$ & $\ldots$ & $\ldots$ & $\ldots$ \\
\hline 38 & 4,5 & 3,5 & 8 \\
\hline
\end{tabular}


Tabel 114 Hasil Akhir Nilai Kelas IPS

\begin{tabular}{|c|l|c|c|}
\hline ID & $\begin{array}{l}\text { Core Factor } \mathrm{N}_{\mathrm{CF}}(\mathrm{S})= \\
(\text { B.Indonesia) }+(\text { Sejarah })+ \\
(\text { Geografi })+(\text { Ekonomi })+ \\
(\text { Sosiologi) } / 5\end{array}$ & $\begin{array}{l}\text { Secondary Factor } \mathrm{N}_{\mathrm{SF}}(\mathrm{S})= \\
(\text { Matematika })+(B . I n g g r i s) \\
+(\text { Fisika })+(\text { Kimia })+ \\
(\text { Biologi) } / 5\end{array}$ & $\begin{array}{c}\text { Nilai } \\
\text { Total }\end{array}$ \\
\hline 1 & 4,7 & 4,1 & 8,8 \\
\hline 2 & 4,8 & 3,9 & 8,7 \\
\hline 3 & 4,7 & 4,1 & 8,8 \\
\hline 4 & 4,5 & 4,3 & 8,8 \\
\hline 5 & 4,6 & 4,1 & 8,7 \\
\hline$\ldots$ & $\ldots$ & $\ldots$ & $\ldots$ \\
\hline 38 & 4,5 & 4,1 & 8,6 \\
\hline
\end{tabular}

5. Membandingkan Hasil Akhir dari IPA dan IPS

Setelah mendapatkan hasil nilai dari masing-masing kelas, kemudian penentuan dengan cara membandingkan hasil persentase yang lebih besar. Jika hasil akhir nilai persentase IPA lebih besar maka direkomendasikan untuk siswa masuk ke kelas IPA. Jika hasil akhir nilai persentase
IPS lebih besar maka direkomendasikan untuk siswa masuk ke kelas IPS. Tetapi jika hasil akhirnya seimbang, maka ketentuan dapat diambil oleh siswa itu sendiri, karena di dalam sistem juga di tampilkan hasil dari kedua persentase antara IPA dan IPS selain itu sistem juga hanya sebatas rekomendasi. Rumus pencarian persentase:

Persentase $(\%)=($ Nilai Total $) * 10$

\begin{tabular}{|c|c|c|c|c|}
\hline ID & Nilai Total IPA & Nilai Total IPS & Persentase IPA & Persentase IPS \\
\hline 1 & 7,8 & 8,8 & $78 \%$ & $88 \%$ \\
\hline 2 & 7,4 & 8,7 & $74 \%$ & $87 \%$ \\
\hline 3 & 7,8 & 8,8 & $78 \%$ & $88 \%$ \\
\hline 4 & 7,8 & 8,8 & $78 \%$ & $88 \%$ \\
\hline 5 & 8,2 & 8,7 & $82 \%$ & $87 \%$ \\
\hline$\ldots$ & $\ldots$ & $\ldots$ & $\ldots$ & $\ldots$ \\
\hline 38 & 8 & 8,6 & $80 \%$ & $86 \%$ \\
\hline
\end{tabular}

Dari percobaan 38 record data tersebut kita bisa melihat contoh untuk ID 1 memiliki 78\% jika masuk kelas IPA dan $88 \%$ jika masuk kelas IPS. Itu artinya berdasarkan hitungan profile matching bahwa ID 1 lebih berpeluang untuk masuk ke kelas IPA dengan persentase $88 \%$.

\subsection{Pembahasan Hasil}

Dari form rekomendasi ini, admin akan menginputkan data-data yang meliputi data profil siswa, dari id data dan nama siswa. Sekaligus menginputkan nilai mata pelajaran yang telah ditentukan, di antaranya nilai matematika, bahasa indonesia, bahasa inggris, fisika, kimia, sejarah, geografi, ekonomi, sosiologi dan biologi. Sistem akan diberikan kondisi, jika salah satu form belum terisi maka tidak dapat diproses. Jika seluruh form telah diisi semua maka penilaian baru bisa diproses. Kondisi lain juga diterapkan untuk inputan ID dan form nilai khusus hanya boleh menginputkan number. Selain itu inputan nilai diberikan maksimal inputan yaitu angka 100 saja. 


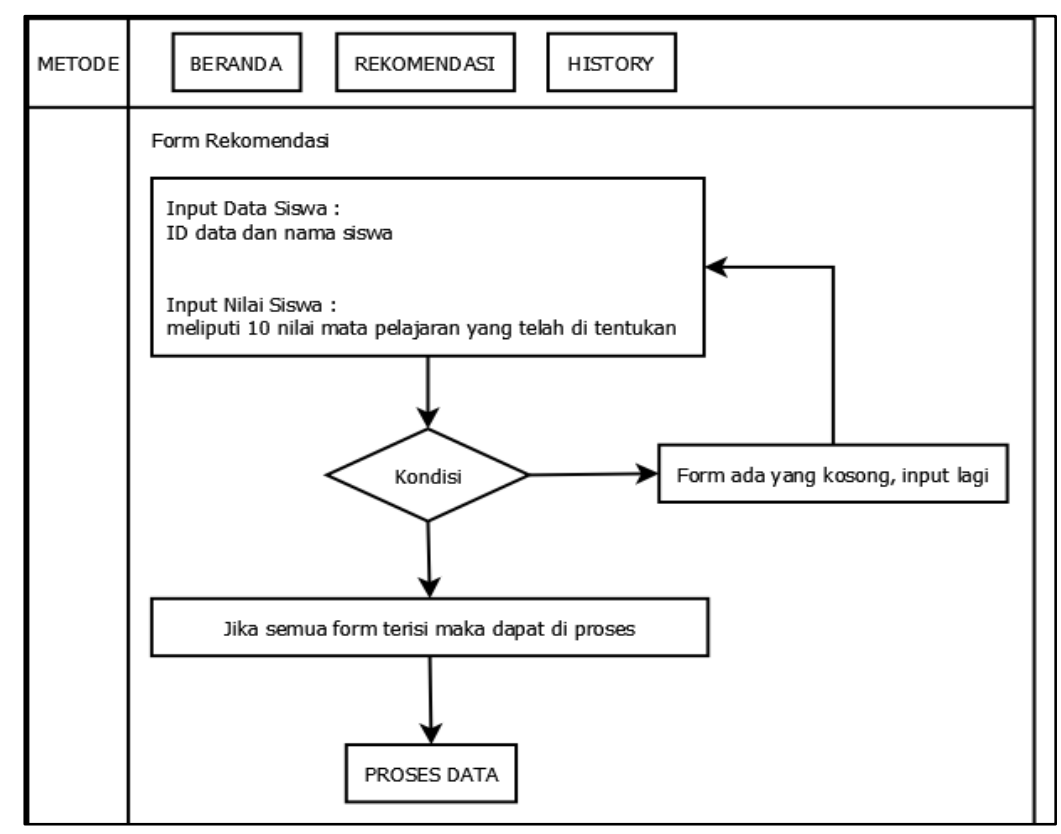

Gambar 2 Input Nilai

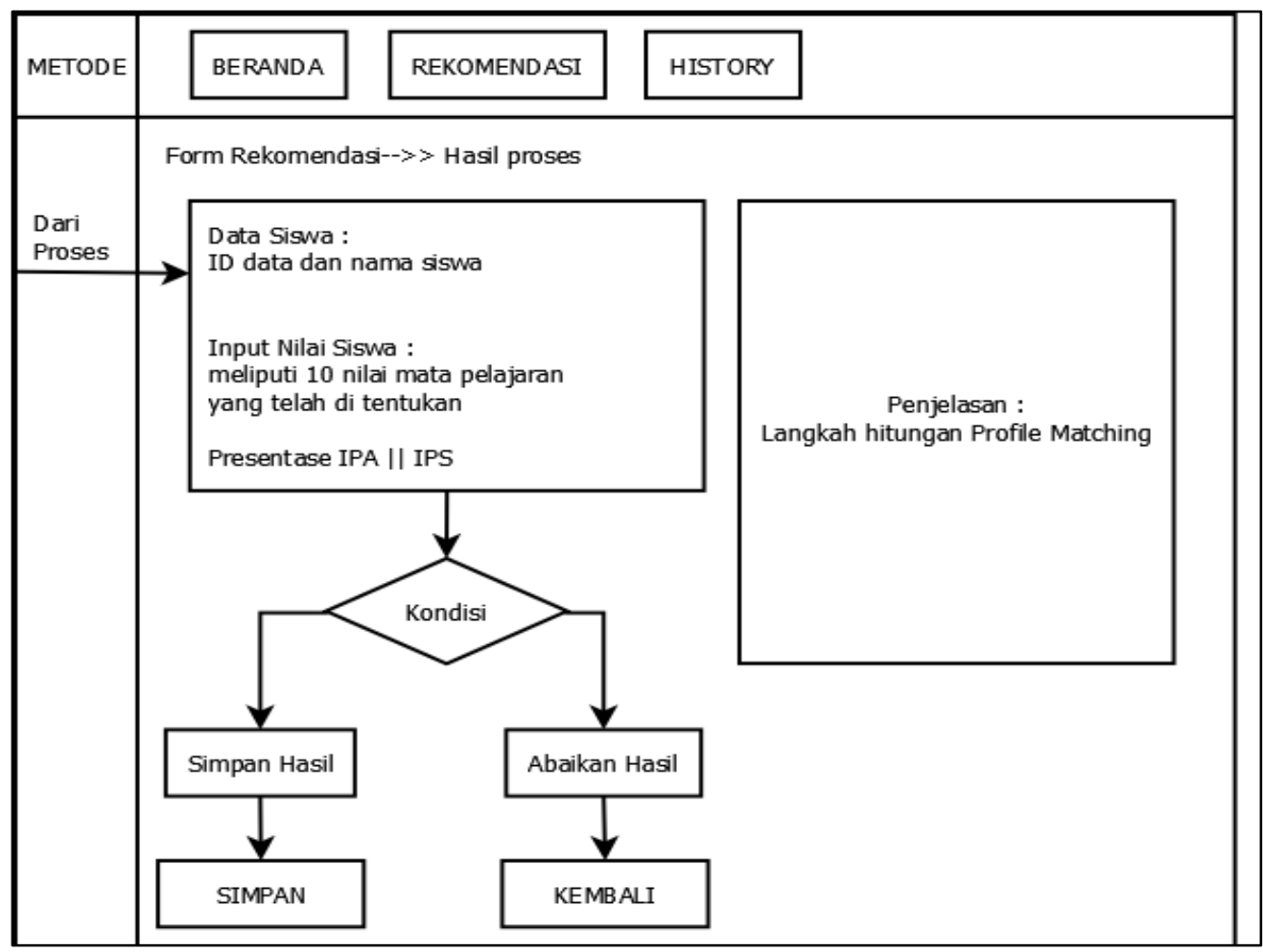

Gambar 3 Simpan Hasil 
Dari hasil proses inputan sebelumnya akan ditampilkan pada form hasil proses, disini admin dapat melihat langkah-langkah perhitungan profile matching. Proses dari awal input nilai siswa di transformasi dulu sesuai dengan ketentuan yang telah di jelaskan seperti di bawah ini :

Tabel 125 Tabel Range Konversi

\begin{tabular}{|c|c|}
\hline Nilai & Konversi \\
\hline$\geq 85$ & 4 \\
\hline $80-84$ & 3 \\
\hline $76-79$ & 2 \\
\hline$\leq 75$ & 1 \\
\hline
\end{tabular}

Setelah melalui tahap transformasi baru nilai diproses sesuai dengan urutan profile matching, termasuk pembobotan nilai GAP. Dan kemudian dihasilkan persentase penjurusan IPA dan IPS.

Evaluasi pada Masing-masing kelompok data akan diuji menggunakan metode decision maker. Berikut ini adalah rentang gap yang digunakan untuk menentukan kelolosan hasil dari masingmasing data.

Tabel 136 Nilai Akurasi Evaluasi Gap (Atma, 2017)

\begin{tabular}{|c|l|}
\hline Range Penilaian & \multicolumn{1}{|c|}{$\begin{array}{c}\text { Kategori } \\
\text { Penilaian }\end{array}$} \\
\hline $0-49$ & Sangat Kurang \\
\hline $50-59$ & Kurang \\
\hline $60-69$ & Cukup \\
\hline $70-84$ & Baik \\
\hline $85-100$ & Sangat Baik \\
\hline
\end{tabular}

Hasil akhir akan ditentukan dengan menghitung nilai akurasi tiap kelompok data uji dengan menggunakan metode decision maker. Data bisa dikatakan akurat jika hasil akhir perbandingan sistem dan hasil decision maker memiliki hasil yang sama. Nilai yang digunakan yaitu nilai dinyatakan lulus dengan nilai baik adalah hasil di atas $75 \%$.

Jika dilihat dari penilaian kelas IPA, dari 192 siswa yang telah diuji terdapat 29 siswa yang memiliki nilai di bawah $75 \%$. Sedangkan jika dilihat dari penilaian IPS, dari 192 siswa semuanya memiliki nilai di atas $75 \%$. Selanjutnya hasil perhitungan akan dihitung nilai akurasinya menggunakan metode decision maker seperti berikut ini (Atma, 2017). Data akurasi diambil dari penilaian jumlah dataset berjumlah 192, dengan kriteria penilaian masing-masing mata pelajaran, berikut adalah rumusnya:

$$
\begin{aligned}
& \text { Nilai akurasi } \\
& =\frac{\text { Jumlah Data Akurat }}{\text { Jumlah sleuruh data }} \times 100 \% \\
& \text { Nilai akurasi ipa }=\frac{163}{192} \times 100 \%=84 \% \\
& \text { Nilai akurasi ips }=\frac{192}{192} \times 100 \%=100 \%
\end{aligned}
$$

Dapat disimpulkan dengan pengujian menggunakan metode decision maker dengan perhitungan profile matching, pada peminatan kelas IPA siswa sebanyak 192 hanya $84 \%$ saja yang positif bisa masuk. Sedangkan jika peminatan kelas IPS seluruh siswa sebanyak 192 semuanya bisa masuk.

\section{KESIMPULAN}

sistem rekomendasi peminatan jurusan dapat membantu siswa SMA kelas $\mathrm{X}$ untuk memberi informasi tambahan. Sehingga siswa yang memiliki minat untuk sekolah pada jurusan IPA atau IPS akan ditambah keyakinannya ketika melakukan daftar ulang di kelas 2 atau kelas XI. Dan akan mengurangi keraguan ketika persentase yang dihasilkan oleh sistem lebih besar dari $75 \%$. Karena angka 75\% merupakan hasil akurasi dan tolak ukur yang masuk kedalam angka Baik dalam sebuah penelitian. Jika dilihat dari hasil percobaan yang dilakukan perhitungan profile matching dapat memberikan perbandingan, pada peminatan kelas IPA siswa sebanyak 192 hanya $84 \%$ saja yang positif bisa masuk. Sedangkan jika peminatan kelas IPS seluruh siswa sebanyak 192 semuanya bisa masuk. Sehingga dengan adanya sistem yang diterapkan dengan metode Profile Matching ini akan dapat membantu sekaligus menjadi tambahan dukungan dalam siswa SMA kelas $\mathrm{X}$ yang ingin mendaftar peminatan sekolah. 


\section{REFERENCE}

Atma, F. D. S., 2017. Implementasi Metode Profile Matching untuk Seleksi Penerimaan Anggota. Jurnal Pengembangan Teknologi Informasi dan Ilmu Komputer, Volume 1, p. 9.

Cahya, 2018. DSS Profile Matching Metode. Contoh Penerapan DSS Profile Matching Metode, 5 April, p. 5.

Dhika, H., Isnain, N. \& Tofan, M., 2019. Manjemen Villa Menggunakan Java Netbeans dan MysQL. Jurnal IKRA-ITH Informatika, Volume 3, p. 7.

Farida, I. N. \& Firliana, R. F., 2016. Implementasi Metode Profile Matching Untuk Evaluasi Potensi Akademik Penjurusan Siswa MAN 2 Kota Kediri. Jurnal Infotel, pp. 156-157.

Farid, I. N. \& Firliana, R., 2017. Perancangan SIstem Rekomendasi Jurusan Berdasarkan Potensi Siswa Menggunakan Metode Profile Matching. Seminar Nasional Teknologi Informasi dan Multimedia, Volume 2, p. 6.

Gautama, E., 2017. Perbanas [nstitute. [Online] Available at: https://dosen.perbanas.id/metode-profile-matching-pencocokan-profil/ [Diakses 25 2019].

id, $\quad$ k. $\quad$ m., $2018 . \quad k o m a n g \quad m y \quad i d . \quad$ [Online] Available at: http://komang.my.id/2018/05/04/metode-profile-matching-dengan-php-mysql/ [Diakses 25 2019].

Kusumawardhany, N., Nurmansyah \& Wardani, A. S., 2019. Penerapan Metode AHP Dan Profile Matching Dalam Penentuan Jurusan SMA. Terbit online pada laman web jurnal, Volume 16, p. 7.

Maghari, A. Y. A. \& Alfere, S., 2018. Prediction of Student's Performance Using Modified KNN Classifiers. International Conference on Engineering \& Future Technology, Volume 1, p. 8.

Monalisa, A., 2015. Sistem Pendukung Keputusan Penentuan Jurusan Dengan Metode Profile Matching Berbasis Web Pada Sekolah SMK TI Airlangga Samarinda. p. 6.

Ningtyas, A. \& Hasugia, H., 2019. Sistem Penunjang Keputusan Penjurusan Siswa Pada SMA Negeri 10 Kabupaten Tangerang Dengan Metode AHP dan Profile Matching. J u r n a l I D E A L I S, Volume 2, p. 9.

Satoto, B. D., khotimah, B. K. \& Iswati, 2015. Pengelompokan Wilayah Madura Berdasarkan Indikator Pemerataan Pendidikan Menggunakan Partition Arround. Journal of Information Systems Engineering and Business Intelligence, Volume 1, p. 8.

Tyas, R. D. O., 2015. Pengembangan Sistem Pakar Diagnosa Penyakit Sapi Potong Dengan Metode Fuzzy K-Nereast Neighbor. Journal of Environmental Engineering \& Sustainable Technology, Volume 2, p. 9. 
Implementasi Metode Profile Matching Pada Penjurusan Bidang Minat Siswa (Studi kasus di SMA 12 Semarang)

Wibowo, A., 2019. Jurusan Ipa Ips SMA. [Online] Available at: $\quad$ https://www.zenius.net/blog/5483/jurusan-ipa-ips-sma [Diakses 1812020$]$.

Wisnu, T., 2019. Peminatan SMP [Wawancara] (14 9 2019).

Wongso, F., 2015. Perancangan SIstem Informasi Penjualan Berbasia Java. Jurnal Ilmiah Ekonomi dan Bisnis, Volume 12, p. 15. 